\title{
THE NEEDS OF TEACHERS OF CHILDREN WITH HEA'RING LOSS WITHIN THE INCLUSIVE EDUCATION SYSTEM
}

\author{
Catherine van Dijk, René Hugo and Brenda Louw
}

Department of Communication Pathology, University of Pretoria

\begin{abstract}
In South Africa, the current movement towards the inclusion of children with disabilities, including children with hearing loss, is likely to have far-reaching consequences for both teachers and learners. Undoubtedly, needs will arise from teachers during the transition, especially in the areas pertaining to the audiological and educational management of children with hearing loss. Therefore, a descriptive research design was developed comprising of a questionnaire survey followed by focus group interviews to determine teachers' needs. The questionnaire survey explored the needs of 664 teachers while focus group interviews were conducted with 19 teachers of children with hearing loss. Teachers were mostly from special schools as only a very small number of children are educated outside these establishments. Findings revealed that, although participants realised the importance of various aspects of development of the child with hearing loss, they generally did not realise the importance of receiving support from an educational audiologist.
\end{abstract}

Key words: children with hearing loss, educational audiologist, educational audiology, inclusion, needs of teachers, teacher support.

\section{INTRODUCTION}

"...because of the invisible nature of the (hearing) impairment, and the general lack of understanding regarding the full impact of hearing impairment upon learning, there is always a need for individuals to work for the child, to ensure that his or her needs as a learner, with hearing impairment are not marginalized or overlooked." (English, 1995 p12).

The education of all learners in South Africa, including children with hearing loss, has undergone profound changes since the end of the apartheid era in 1994. The educational system changed from a racially segregated system to a non-racial inclusive system. Prior to 1994 , specialised education was characterised by the following (Education White Paper no. 6, 2001):

- education and support were predominantly provided for a small percentage of learners with disabilities within special schools or classes;

- where provided, specialised education and support were rendered on a racial basis, with the best human, physical and material resources reserved for the White population;

- most learners with disabilities were either excluded from the system or were mainstreamed by default;

- the curriculum and educational system as a whole, generally failed to respond to the diverse needs of the learner population with disabilities and this resulted in massive numbers of academic failures; and

- although attention was given to the schooling phase with regard to "special needs and support", the other levels or bands of education were seriously neglected.

The government is in the process of rectifying the abovementioned injustices to learners with disabilities and proposes an inclusive education system which aims to "... promote education for all and foster the development of inclusive and supportive centres of learning that would enable all learners to participate actively in the education process so that they could develop and extend their potential and participate as equal members of society" (Education White Paper no. 6, 2001 p5).
The South African Education White Paper no. 6 (2001) states that the inclusive education system will have a variety of different placements ranging from ordinary schools to special schools/resource centres with the goal of uncovering and addressing barriers to learning, and recognising and accommodating the diverse learning needs among learners. The inclusive education system will have a wider spread of educational support services that will be created in line with what learners with their specific disabilities require. Schools will be divided into three categories: ordinary schools, full-service schools and special schools/resource centres. However, these three categories of placement are by no means an attempt to revert to the previous education system of separation of children with disabilities from other regular children. The difference lies in the placement strategy: learners are classified according to their need for support and not according to their physical limitations.

The current movement toward inclusion of children with disabilities, including those with hearing loss, is likely to have far-reaching consequences for teachers, parents and learners (Keith \& Ross, 1998). More specifically, the teacher, in order to successfully fulfill his/her role, will have to confront many challenges related to the audiological and educational management of children with hearing loss (English, 1995). The rationale for this statement is based on the complexities and/or characteristics related to the disability of a hearing loss (Johnson, Benson \& Seaton, 1997). Children, except those exclusively immersed in signing environments, learn language primarily through the auditory pathways (English, 1995; Lynas, 1994). Therefore, a hearing loss often negatively impacts on the development of these children's auditory, language, speech, communication, literacy, academic, and psychosocial skills within the inclusive environment (Johnson et al., 1997). Children with hearing loss who are primarily educated within a signing environment will also be affected by the transition to an inclusive education system due to, amongst other reasons, communication barriers that may exist between them and their hearing peers and teachers (Moores, 1996).

The educational audiologist is uniquely skilled in mana- 
ging the effects of hearing loss on the child's educational development, and is a crucial member on the educational team. The educational audiologist, as specialist in the management of children with hearing loss, is able to offer a wide range of support and assistance to teachers as well as to these children in the inclusive education system (Johnson et al., 1997). When teachers receive appropriate educational audiology services, they are enabled to provide quality education that strives to maximize the full potential of every child with hearing loss (English, 1995).

The responsibilities of the educational audiologist continues to evolve and mature in response to changing educational trends and evolving government policy (English, 1995). The most recent guidelines for audiology services in schools as proposed by the American Speech-Language-Hearing Association are prevention of hearing loss, conservation of hearing, assessment, habilitation and amplification of the child with hearing loss, education and training of the educational team, assistance and support to the child and family, monitoring and follow-up of clients, and research in the field of educational audiology to stay abreast of new trends. (ASHA, 1993).

It is understandable that transition to an inclusive system will not be successful without additional research and training efforts. As a possible first step in this process, it is important to determine the opinions, ideas and plans of teachers for children with hearing loss within the inclusive education system. More specifically, the needs of teachers of children with hearing loss have to be determined in order to seek solutions to provide support to teachers in their new role. Supporting the teacher through educational audiology services will enhance the quality of education for all children with hearing loss (English, 1995; Johnson et al., 1997; Webster \& Wood, 1989).

\section{METHOD}

\section{Aims and objectives}

The aim of the study was to determine the needs of teachers of children with hearing loss regarding their audiological and educational management within the inclusive education system. In order to achieve this aim, the following objectives were formulated:

- to determine and describe the needs of teachers regarding their knowledge of educational audiology, and

- to determine and describe the needs of teachers regarding the audiological and educational management of children with hearing loss.

\section{Research design}

The research design was a qualitative paradigm that was descriptive and contextual in nature (Leedy \& Ormrod, 2001; Mouton \& Marais, 1996; Schurink, 1998). A qualitative analysis of teachers' needs regarding the management of children with hearing loss within the inclusive education system, made it possible to determine their current needs. By means of quantitative analysis, findings could be interpreted in terms of their generalizability to the whole population of teachers of children with hearing loss in South Africa.

The primary research protocol comprised of a descriptive survey by questionnaire followed by supplementary focus group interviews (Stewart \& Shamdasani, 1990). The use of a combination of research methods had the potential of enhancing the quality of data collection and reducing the chance of bias (Berg, 1998). Utilising different methods enabled the formation of a comprehensive depiction of the needs of teachers of children with hearing loss within an inclusive education system.

\section{Selection and description of participants}

The procedures for selection and the description of schools and teachers follow.

\section{Selection and description of schools}

All 35 schools currently providing for children with hearing loss in the nine provinces of South Africa were identified from a list obtained from the Deaf Federation of South Africa (DEAFSA, 2001a) and were included in the questionnaire survey (See Appendix A). All these schools were targeted, to ensure that the results obtained were representative of teachers of children with hearing loss in South Africa (Reid \& Gough, 2000). Schools that focused exclusively on the pre-school phase were excluded. These schools were excluded because they are primarily privately owned and may not be directly affected by plans for the transition to an inclusive education system (Education White Paper no. 6, 2001).

Two Gauteng schools on the list of 35 schools were purposefully (Leedy \& Ormrod, 2001) selected for participation in the focus group interviews. Purposeful selection facilitated analysis of differences between pre-determined heterogeneous groups (Morgan, 1997) namely, schools that mainly promote spoken language and schools that mainly promote Sign Language.

Questionnaires (See Appendix B) were sent to 32 of the total of 35 schools, thereby excluding the three schools used during the pilot study and in the focus group interviews, in order to avoid data-contamination (Neuman, 1997). After completion of the survey, 27 of the 32 schools ( $84 \%$ ) returned their questionnaires. Of the total number of schools providing for children with hearing loss in South Africa, 27 of the 35 schools $(77 \%)$ participated in the survey. The schools in the survey represented all eight provinces that had schools for children with hearing loss, namely: Eastern Cape, Free State, Gauteng, KwazuluNatal, Limpopo, Mpumalanga, North West, and Western Cape. This sample was a very good statistical representation of the total population of schools in South Africa (Huysamen, 1998);

Table 1 provides a description of the schools included in the questionnaire survey. (Refer to page 24)

\section{Selection and description of teachers}

The procedures for selection are described followed by a description of the participants.

\section{Participants in the questionnaire survey}

The participants had to be employed as teachers by any of the schools mentioned above in order to ensure that they had teaching experience with children with hearing loss and that they were familiar with the educational-setting in South Africa. Questionnaires were sent to 664 of the total population of 769 teachers of the 32 schools, thereby excluding the participants 
Table 1: Description of schools participating in the questionnaire survey $(n=32)$

\begin{tabular}{|c|c|c|c|c|c|c|}
\hline Province & School & $\begin{array}{l}\text { Nature of } \\
\text { School }\end{array}$ & $\begin{array}{l}\text { Communication } \\
\text { Instructional } \\
\text { Approach }\end{array}$ & $\begin{array}{c}\text { Educational } \\
\text { Audiologists } \\
\text { Posted at } \\
\text { School }\end{array}$ & $\begin{array}{c}\text { Teachers } \\
\text { Educating } \\
\text { Children with } \\
\text { Hearing Loss }\end{array}$ & $\begin{array}{c}\text { Number of } \\
\text { Leamers } \\
\text { with Hearing } \\
\text { Loss }\end{array}$ \\
\hline \multirow[t]{4}{*}{ Eastern Cape } & 1 & hearing loss & \multirow{2}{*}{ Sign Language } & 0 & 38 & 300 \\
\hline & 2 & $\begin{array}{l}\text { hearing loss \& } \\
\text { visual impairment }\end{array}$ & & 1 & 35 & 120 \\
\hline & 3 & $\begin{array}{l}\text { regular school \& } \\
\text { unit for hearing loss }\end{array}$ & Oral-Aural & 0 & 5 & 40 \\
\hline & 4 & hearing loss & Total Communication & 1 vacancy & 11 & 110 \\
\hline \multirow[t]{2}{*}{ Free State } & 5 & \multirow{2}{*}{$\begin{array}{l}\text { hearing loss \& } \\
\text { visual impairment }\end{array}$} & \multirow{2}{*}{ Sign Language } & 1 vacancy & 16 & 160 \\
\hline & 6 & & & 0 & 20 & 210 \\
\hline \multirow[t]{5}{*}{ Gauteng } & 7 & $\begin{array}{l}\text { hearing loss, visual } \\
\text { impairment \& } \\
\text { physical impairment }\end{array}$ & Total Communication & 2 & 14 & 40 \\
\hline & 8 & \multirow{4}{*}{ hearing loss } & \multirow[t]{2}{*}{ Total Communication } & 1 & 16 & 102 \\
\hline & 9 & & & 1 vacancy & 22 & 170 \\
\hline & 10 & & Sign Language & 1 & 25 & 161 \\
\hline & 11 & & Oral-Aural & 0 & 35 & 189 \\
\hline \multirow[t]{8}{*}{ Kwazulu-Natal } & 12 & hearing loss & \multirow{4}{*}{ Total Communication } & 1 vacancy & 20 & 150 \\
\hline & 13 & & & 1 & 14 & 108 \\
\hline & 14 & & & 1 & 18 & 265 \\
\hline & 15 & & & 2 & 28 & 240 \\
\hline & 16 & & \multirow{3}{*}{ Sign Language } & 1 vacancy & 30 & 275 \\
\hline & 17 & & & 1 & 27 & 241 \\
\hline & 18 & & & 0 & 3 & 12 \\
\hline & 19 & & Bilingual/Bicultural & 1 & 25 & 99 \\
\hline \multirow[t]{4}{*}{ Limpopo } & 21 & $\begin{array}{l}\text { hearing loss \& } \\
\text { visual impairment }\end{array}$ & \multirow{3}{*}{ Sign Language } & 1 & 16 & 189 \\
\hline & 23 & $\begin{array}{l}\text { hearing loss, visual } \\
\text { impaiment \& } \\
\text { physical impairment }\end{array}$ & & 1 vacancy & 21 & 197 \\
\hline & 24 & \multirow[t]{2}{*}{ hearing loss } & & 1 & 23 & 240 \\
\hline & 22 & & Oral-Aural & 0 & 2 & 36 \\
\hline Mpumalanga & 20 & $\begin{array}{l}\text { hearing loss, visual } \\
\text { impairment \& } \\
\text { cognitive impairment }\end{array}$ & Total Communication & 0 & 6 & 60 \\
\hline Northern Cape & \multicolumn{6}{|c|}{ No schools providing for children with hearing loss to date } \\
\hline \multirow[t]{2}{*}{ North West } & 25 & hearing loss & Sign Language & 0 & 7 & 60 \\
\hline & 26 & hearing loss & Total Communication & $\overline{0}$ & 30 & 300 \\
\hline \multirow[t]{6}{*}{ Western Cape } & 27 & hearing loss & Total Communication & 1 & 30 & 200 \\
\hline & 28 & hearing loss & Oral-Aural & 1 & 15 & 70 \\
\hline & 29 & hearing loss & Total Communication & 2 & 15 & 200 \\
\hline & 30 & hearing loss & Oral-Aural & 1 & 13 & 84 \\
\hline & 31 & hearing loss & Total Communication & 1 & 29 & 150 \\
\hline & 32 & hearing loss & Oral-Aural & 2 & 55 & 506 \\
\hline & & & & TOTAL: & 664 teachers & 6215 learners \\
\hline
\end{tabular}


used during the pilot study and focus group interviews. A return rate of $364(55 \%)$ completed questionnaires was achieved. This return rate is considered good as the general return rate for mailed questionnaires is usually in the region of $20 \%$ (Berg, 1998). Three hundred and sixty four of the total population of 769 teachers $(47 \%)$ providing for children with hearing loss in South Africa participated in the questionnaire survey. The sample consisted of 75 of the 165 teachers $(45 \%)$ who mainly promote spoken language, and 289 of the 604 teachers (48\%) who mainly promote Sign Language.

It was concluded that the sample was representative of the total population of teachers providing for children with hearing loss in South Africa considering the following (Huysamen, 1998):

- participants represented all eight provinces that have schools providing for children with hearing loss in South Africa;

- participants represented $77 \%$ of all the schools providing for children with hearing loss;

- participants from the sub-groups representing the two communication instructional approaches were represented nearly equally percentage-wise; and

- a large number of completed questionnaires $(n=364)$ were received from participants.

Figure 1 provides a summary of the description of participants included in the questionnaire survey.
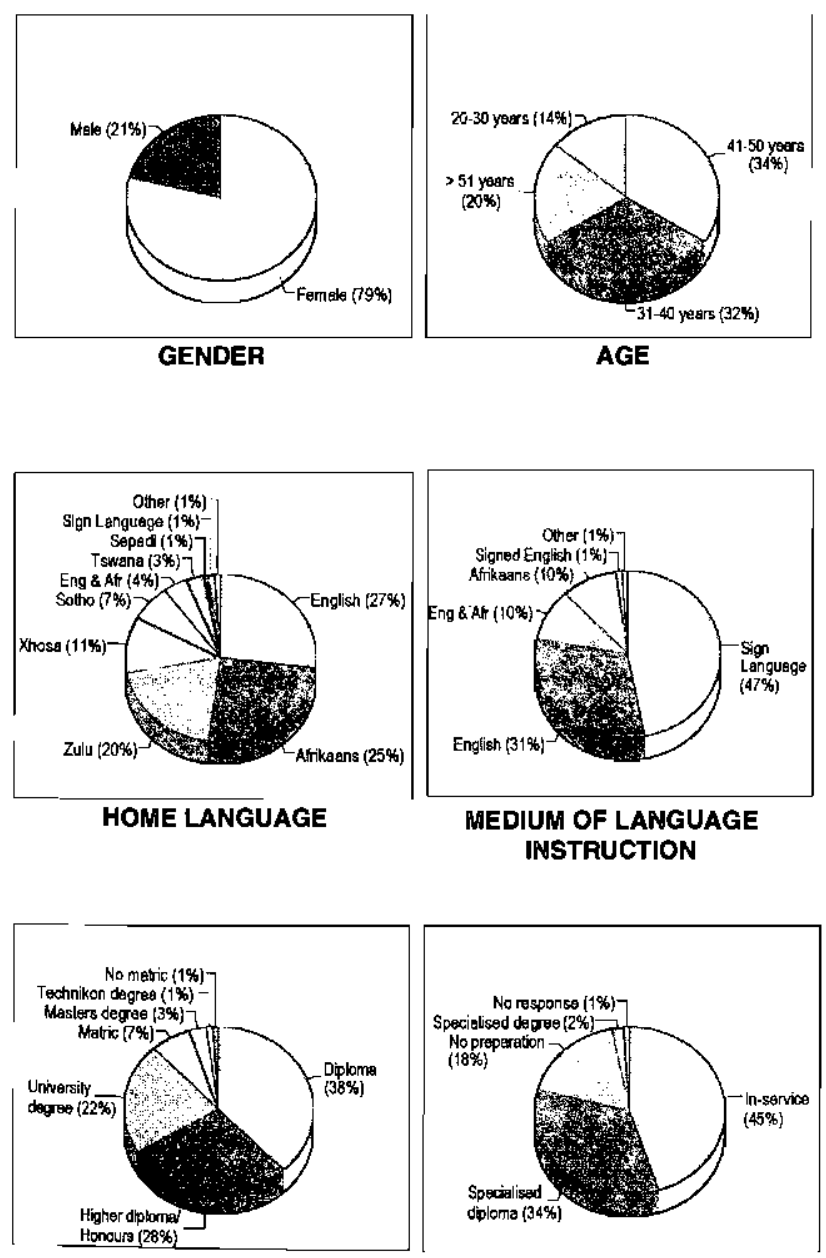

QUALIFICATIONS

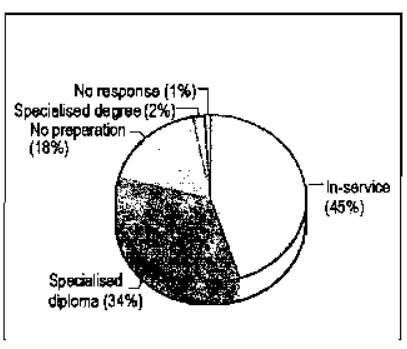

SPECIALISED TRAINING

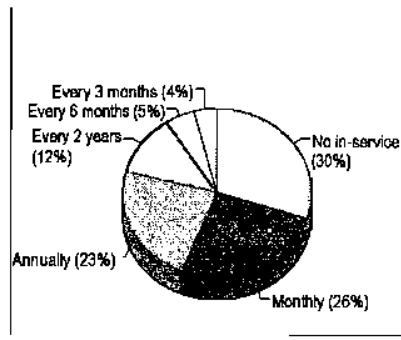

IN-SERVICE TRAINING

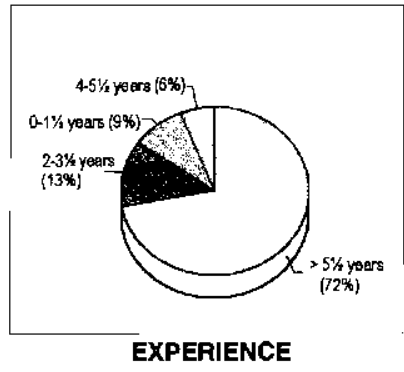

EXPERIENCE

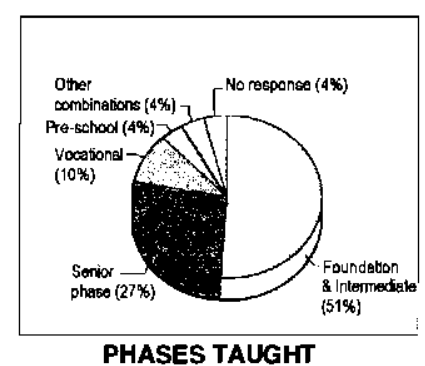

PHASES TAUGHT

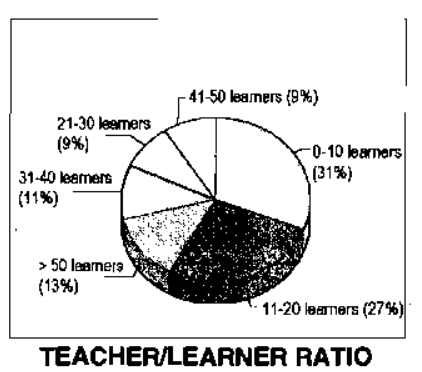

Figure 1: Description of participants in the questionnaire survey $(n=364)$

\section{Participants in focus group interviews}

Participants were randomly selected from both the junior and senior phases to ensure representativeness during the focus group interviews (Leedy \& Ormrod, 2001).

Two focus groups were conducted with each selected school, totaling four separate focus group interviews. One school was representative of teachers mainly promoting spoken language and the other school represented teachers who mainly promote Sign Language. Five participants were randomly selected from the junior phase of a school (ranging from preschool to grade 6) for the first focus group interview. For the purposes of the second focus group interview, five participants were randomly selected from the senior phase of a school (ranging from grade 7 to vocational phase). These selection procedures allowed for a more equal distribution of participants among the teaching phases.

The selection of five teachers per focus group interview was regarded as a sufficient number of participants, because according to Morgan (1997), a smaller number of participants are required if the participants have a high level of involvement with the topic and a smaller group allows the researcher to exercise more control over the active involvement of each participant. Furthermore, five teachers were selected for each focus group interview, because findings from the pilot study revealed this to be a desirable number of participants for active focus group participation.

Teachers who met the selection criteria and acted as participants in the focus group interviews, are described in Figure 2.

\section{Data collection instruments}

A questionnaire (See Appendix B) and focus group interviews served as data collection instruments for the study. 


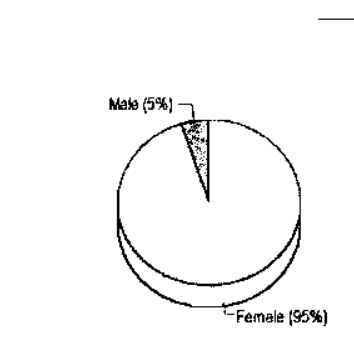

GENDER

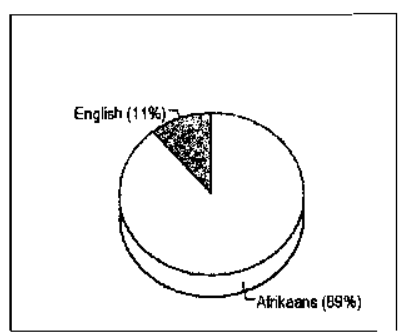

HOME LANGUAGE

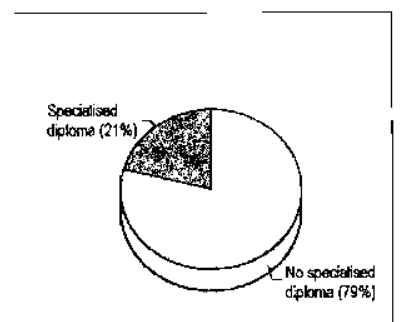

SPECIALISED TRAINING
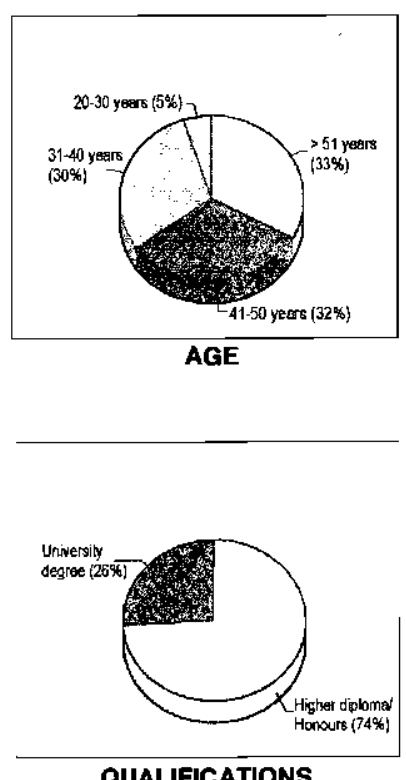

QUALIFICATIONS

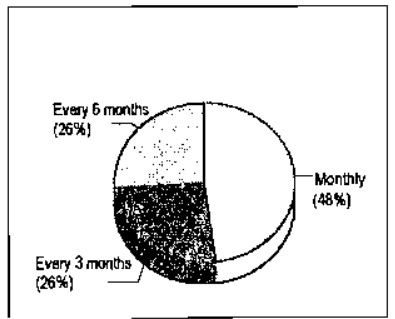

IN-SERVICE TRAINING

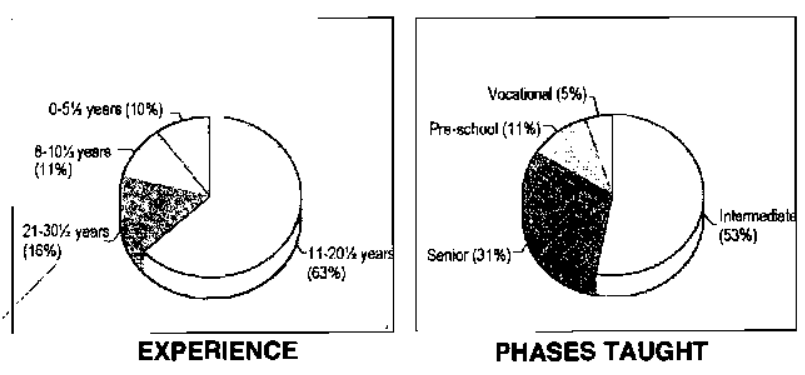

Figure 2: Description of participants in focus group interviews $(n=19)$

\section{The questionnaire}

A questionnaire, as a data collection instrument, was compiled for this study and considered the most advantageous for the following reasons (Berg, 1998; Neuman, 1997):

- a wide geographical area (in this case the whole of South Africa) could be included in the survey;

- questionnaire surveys are more time-effective, since a large number of responses can be obtained in a limited period of time;

- questionnaire surveys are more cost-effective in comparison with face-to-face contact with participants; and

- a questionnaire is completed in privacy, and participants are therefore more likely to express their true opinions and views.
However, the main disadvantage of a mailed questionnaire is that there tends to be a poor response rate (Neuman, 1997). This limitation was acknowledged, and guidelines in the literature were followed in order to facilitate a good response rate. These guidelines included, telephonic contact with principals prior, during and after the survey, sending questionnaires by courier services, and supplying postage-paid, self-addressed envelopes that were registered at the post-office, to ensure that these parcels could be tracked within the postal system (Berg, 1998; Neuman, 1997).

The questionnaire was comprised of 30 questions distributed across 12 pages, and consisted of three sections. Although a 12-page questionnaire seemed lengthy, most of the questions were closed-ended. Therefore, the duration for completion (approximately 20 minutes) was considered as being within reasonable limits (Berg, 1998). Appendix C depicts the development and description of the questionnaire in terms of the content included and the rationale for inclusion.

\section{Focus group interviews}

The use of focus group interviews were regarded as an important data collection instrument in the current study for the following reasons (Morgan, 1997; Stewart \& Shamdasani, 1990):

- some of the quantitative results obtained from the questionnaire survey could be qualitatively interpreted;

- concentrated amounts of data, on precisely the topic of interest could be extracted;

- new ideas and creative concepts could be stimulated;

- complex behaviours and opinions could be more clearly studied; and

- participants could be made stakeholders in the research process, when they were given a chance to freely voice their feelings and suggestions.

The most common disadvantage of utilising focus group interviews is that the small numbers of participants included in focus group interviews limits the generalisation of findings to the larger population (Stewart \& Shamdasani, 1990). Therefore, this data collection method was not used in isolation in this study, but was combined with a questionnaire survey in order to make findings more generalizable.

The focus group interview consisted of two topics to guide the participants during the focus group interviews (Stewart \& Shamdasani, 1990). The first topic of discussion was: "How do you feel about the inclusive education system and children with hearing loss?". This topic remains controversial internationally amongst many teachers of children with hearing loss (English, 1995; Moores, 1996). By obtaining participants' views on issues such as the challenges they foresee, and the solutions they suggest, determination of the role of the educational audiologist in attempting to address these challenges will be aided.

The second topic discussed was: "How do you feel about the role of a hearing therapist (audiologist) in the inclusive education system?". By determining teachers' need for support and the challenges of current service delivery by the educational audiologist, appropriate service delivery can be planned.

The duration of focus groups interviews was approximately 30 minutes each and was conducted on the school premises on separate days during in-service training time.

Audio recordings were made of the focus group inter- 
views, in order to facilitate written transcriptions. In addition, the researcher made notes of distinct nonverbal behaviour, such as frowning, gesturing or winking, that aided the interpretation of the content of the audiocassette recordings at a later stage (Stewart \& Shamdasani, 1990).

\section{DATA ANALYSIS}

The data analysis procedures are described.

\section{Data analysis of the questionnaire survey}

Analysis of questionnaire data' included quantitative analysis where percentages and frequencies of responses were determined, as well as qualitative analysis, where responses were described in detail.

Data obtained from the questionnaire survey were analyzed by means of descriptive statistics in order to describe and summarise the collection of scores obtained. Descriptive statistics physically reduce large amounts of data and facilitate the drawing of conclusions about them (Bless \& Higson-Smith, 1995).

Raw data transferred onto spreadsheets were analyzed by means of computer software, namely SAS/STAT ${ }^{8}$ (version 8) from the SAS Institute.

Responses to open-ended questions were abstracted into main ideas in order to categorise answers of all the participants into more manageable units (Berg, 1998).

\section{Data analysis of focus group interviews}

Analysis of data obtained from the focus group interviews was qualitative in nature. The Cut-and-Paste technique described by Stewart and Shamdasani (1990) was used in order to analyze and interpret data obtained from the focus group interviews. This technique has four distinct steps that are critical in order to establish the dependability of data recording and analysis (Reid \& Gough, 2000).

The first step includes the recording of data. During the second step, the researcher identified units from the transcript that were relevant to the research aims (Stewart \& Shamdasani, 1990). These units were underlined by means of a word processing program. In step three, the researcher reread the transcript and then identified by selecting themes that corresponded with those of the questionnaire items. The units relating to these themes were colour-coded according to the themes and were then cut and pasted into their respective classifications using a word processing program. These sorted themes provided the basis for further categorisation of content (Stewart \& Shamdasani, 1990). Finally, during step four, units that supported each theme were further categorised in order to form an interpretative representation of responses. These excerpts were numbered and were presented within a format that clearly captured the findings of each theme (Stewart \& Shamdasani, 1990).

\section{ETHICAL CONCERNS}

Research ethics define what is legitimate and moral during research procedures (Neuman, 1997). According to Strydom (2002), ethical issues can be divided into harm to participants, informed consent, deception of participants, violation of privacy, researcher competence, cooperation with collaborators, and release of findings. The researcher attempted to conduct herself ethically in each of these areas.

Participants were not harmed in a physical and/or emotional manner during the research (Strydom, 2002). Participants were disadvantaged if they chose not to participate in the research, and this was clearly stated to them.

A covering letter accompanied by an informed consent form was provided to all participants, explaining the aims of the research, the procedures to be followed, and that participation in the study was entirely voluntary (Strydom, 2002). Therefore, participants were not coerced or manipulated into volunteering, and had to give informed consent in order to participate in the research project (Berg, 1998). Participants were also free to withdraw from the research whenever they chose to do so (Strydom, 2002).

The researcher ensured that participants were not deceived in any way as to the goal of the study, the purpose, the experiences that they were subjected to, or the use of the data accumulated, as these were clearly stipulated these points in a covering letter (Strydom, 2002).

It was essential that the researcher acted with the necessary sensitivity where privacy of participants was concerned. Therefore, respondents were not requested to reveal their names. In addition, the participants were assured of the confidentiality of their responses by removing any element from the research records that may have indicated the participant's identity (Berg, 1998).

The researcher assured all parties involved of her competence, skill and thorough preparation to undertake the investigation at hand (Strydom, 2002). The research design, data collection instruments, and procedures were reviewed by experienced research supervisors prior to the main study.

Prior to conducting the fieldwork, permission to carry out the research was obtained from the relevant authorities, namely: Research Ethics Committee: Faculty of Humanities, University of Pretoria by submitting a research proposal prior to the intended study. Permission was also obtained from the various departments of Education, the school principals, as well as the participants (Strydom, 2002).

Questionnaires were distributed and completed during break-time so as not to interfere with regular school duties. Focus group interviews were conducted after school hours during a time allocated for in-service training so as not to have caused interference with participants' regular school hours. !

The participants were informed that the information obtained from the research would only be used for research purposes and would not be misused or used to cause any harm to the reputation of individual participants or to the professional groups involved (Neuman, 1997). After completion of the research, a summary of findings was made available to the departments of education as well as the schools that participated in the research (Strydom, 2002).

\section{RESULTS}

\section{Knowledge of educational audiology}

Averages of the results were determined in order to obtain a broad overview of the findings of both sub-groups of 
Table 2: Knowledge of educational audiology

\begin{tabular}{|l|c|c|c|c|}
\hline \multicolumn{1}{|c|}{ Areas of knowledge } & \multicolumn{2}{|c|}{$\begin{array}{c}\text { Participants who mainly promote } \\
\text { spoken language (n=75) }\end{array}$} & \multicolumn{2}{c|}{$\begin{array}{c}\text { Participants who mainly promote } \\
\text { Sign Language (n=289) }\end{array}$} \\
\hline & $\begin{array}{c}\text { Should have } \\
\text { knowledge }\end{array}$ & $\begin{array}{c}\text { Requires support to } \\
\text { obtain this knowledge }\end{array}$ & $\begin{array}{c}\text { Should have } \\
\text { knowledge }\end{array}$ & $\begin{array}{c}\text { Requires support to } \\
\text { obtain this knowledge }\end{array}$ \\
\hline Hearing loss & $85 \%$ & $68 \%$ & $68 \%$ & $58 \%$ \\
\hline Negative impact of a hearing loss & $92 \%$ & $73 \%$ & $66 \%$ & $64 \%$ \\
\hline Maximising residual hearing & $87 \%$ & $47 \%$ & $73 \%$ & $42 \%$ \\
\hline
\end{tabular}

participants on the questionnaire survey. The data is set out in Table 2. Some excerpts from the focus group interviews are provided in the text.

\section{Hearing Loss and the Negative Impact of a Hearing Loss}

Participants of both sub-groups, namely teachers who mainly promote spoken language and teachers who mainly promote Sign Language, strongly recommended, that teachers have knowledge of the various aspects of hearing loss, but, a smaller number of participants, indicated that teachers required support in the acquisition of this knowledge. The teachers' need for knowledge of the various aspects of hearing loss were confirmed by two excerpts from the focus group that reveal teachers' awareness of the importance of knowledge on hearing loss. "... hearing aids are of the utmost importance, a child cannot afford to be sitting in class without an aid for even one single day..." (participant mainly promoting spoken language). "... we would have liked to know more about it (annual audiograms of pupils) ...we do know how the audiogram works, but if we could compare it with the results of the previous year... if we knew how..." (participant mainly promoting Sign Language)

Furthermore, participants who mainly promote Sign Language, indicated less need than the other sub-group for the acquisition of knowledge and support in the various aspects of hearing loss.

Participants of both sub-groups, namely teachers who mainly promote spoken language and teachers who mainly promote Sign Language, recommended that teachers should have knowledge about the negative impact of a hearing loss on the various areas of development. The teachers' high regard for knowledge about the negative impact of a hearing loss is supported by focus group comments: "... our children have a big problem with abstract thinking... with Maths... they experience many difficulties... they don't have insight, they are extremely bound by their concrete world..." (participant mainly promoting spoken language); "... ever so often he is embarrassed, because he didn't do his work or know what was going on, because he didn't hear..." (participant mainly promoting Sign Language).

An overview of results indicated that participants who mainly promote Sign Language indicated less need (66\% vs $64 \%$ ) than the other sub-group for the acquisition of knowledge and support with regard to the impact of hearing loss.

Further statistical analysi's regarding knowledge about hearing loss and the negative impact of a hearing loss revealed that some of the variables rendered chi-square $\left(\chi^{2}\right)$ values greater than the critical value based on $p \leq .05$ Variables that were considered included: gender, age, teaching experience, medium of language instruction, highest educational qualification, specialised training in hearing loss, in-service training as well as the teacher/learner ratio in the classroom. Chi-square values greater than the critical value indicated that these variables significantly influenced the participants' need for support in learning about hearing loss. However, none of these variables significantly influenced the participants' need for support in learning how to address the negative impact of hearing loss.

Participants who mainly promote spoken language, with no specialised training in hearing loss, indicated a greater need for support in learning about the classification of the types of hearing loss than participants who had received specialised training. Participants who mainly promote spoken language and that have received in-service training less frequently than once per month, indicated a greater need for support in learning about audiograms and FM systems.

Participants who mainly promote Sign Language that had more than 20 learners in their classrooms indicated a greater need for support in learning about the trouble-shooting of a hearing aid.

\section{Maximising of Residual Hearing}

Participants of both sub-groups, namely teachers who mainly promote spoken language and teachers who mainly promote Sign Language, recommended (87\% and $73 \%$ respectively) that teachers have knowledge about how to maximise residual hearing. However, very few participants $(47 \%$ and $42 \%$ respectively) indicated that teachers required support in the acquisition of this knowledge. Two excerpts from the focus group interviews confirm that teachers value knowledge on maximising residual hearing: "...the physical environment of the child should provide for his hearing impairment..." (participant mainly promoting spoken language); “...then you first have to send him back to the hostel to get his hearing aids... many of the older children have that don't-care attitude about their hearing aids..." (participant mainly promoting Sign Language).

Statistical analysis of variables and the maximising of residual hearing revealed chi-squar values greater than the critical value which indicated that the variables a significantly influenced the participants' need for support in learning how to maximise residual hearing. 
Participants who mainly promote spoken language and who had diplomas, indicated a greater need for support in learning about the advocacy of FM systems in the school setting, than participants with higher qualifications. Participants who mainly promote spoken language, with no specialised training in hearing loss, indicated a greater need for support in learning about the instruction of speech-reading skills to children with hearing loss than participants with specialised training. Participants who mainly promote spoken language, with more than ten learners in their classrooms, indicated a greater need for support in learning about the enhancement of classroom acoustics.

Participants who mainly promote Sign Language and who had diplomas as their highest qualifications, indicated a greater need for support in the acquisition of knowledge in various areas. These areas included, how to advocate the use of FM systems in the school setting, the enhancement of correct listening skills, as well as knowledge in the instruction of speech-reading skills. Participants who mainly promote Sign Language, with more than 20 learners in their classrooms, indicated a greater need for support in learning about the instruction of speech-reading skills. Participants who mainly promote Sign Language who had received in-service training less frequently than once per month, indicated a greater need for support in learning about the identification of noise levels, as well as learning about the encouragement of continual hearing aid use.

\section{Audiological and educational management of the child with hearing loss}

Averages were calculated in order to condense findings of both sub-groups of participants as obtained from the questionnaire survey. These averages are presented in Table 3. The findings in Table 3 are discussed in terms of the most outstanding features, and items viewed similarly by participants were grouped together. Some focus group excerpts are presented.

\section{Speech Production Skills}

From Table 3 it is clear that participants of both sub-groups strongly recommended that teachers take various intervention steps in order to develop the speech production skills of the child with hearing loss. The majority of participants of both sub-groups, namely teachers who mainly promote spoken language and teachers who mainly promote Sign Language recommended $(80 \%$ and $60 \%)$ respectively that teachers receive professional support in order to develop the speech production skills of the child with hearing loss. Participants' recommendations for the development of speech production skills are echoed in the following excerpts from the focus group interviews: "... we want them (the educational audiologists) to...motivate the children to speak, it will be a great help if there is someone to monitor each child..." (participant mainly promoting spoken language); "... they (the educational audiologists) could help... with the pronunciation and forming of words in subjects, where they have to know big words..." (participant mainly promoting Sign Language). Results revealed that participants who mainly promote spoken language generally indicated a greater need for support $(80 \%)$ in the development of speech production skills than did participants who mainly promote Sign Language.

\section{Language, Communication, Literacy and Academic Skills}

Results indicated that participants of both sub-groups strongly recommended that teachers take various intervention steps in order to develop skills in language, communication, literacy and academics. However, only an average to belowaverage amount of support in these areas of development was deemed to be required. Excerpts from the focus groups highlighted participants' commitment to the development of language skills: “... we are specifically trained to know where language starts, in other words, we know a small little thing such as eye contact... is a form of language..." (participant mainly promoting spoken language); "... definitely in the area of Sign Language they (the educational audiologists)... can make more contributions in terms of planning the language lessons..." (participant mainly promoting Sign Language). The development of communication skills was highlighted in the

Table 3: Audiological and educational management of the child with hearing loss

\begin{tabular}{|l|c|c|c|c|}
\hline Knowledge of development & \multicolumn{2}{|c|}{$\begin{array}{c}\text { Participants who mainly promote } \\
\text { spoken language (n=75) }\end{array}$} & $\begin{array}{c}\text { Participants who mainly promote } \\
\text { Sign Language (n=289) }\end{array}$ \\
\hline & $\begin{array}{c}\text { Should take various } \\
\text { intervention steps }\end{array}$ & $\begin{array}{c}\text { Requires support to } \\
\text { execute these steps }\end{array}$ & $\begin{array}{c}\text { Should take various } \\
\text { intervention steps }\end{array}$ & $\begin{array}{c}\text { Requines support to } \\
\text { execute these steps }\end{array}$ \\
\hline Speech production skills & $78 \%$ & $80 \%$ & $75 \%$ & $60 \%$ \\
\hline Language skills & $90 \%$ & $53 \%$ & $74 \%$ & $45 \%$ \\
\hline Communication skills & $92 \%$ & $57 \%$ & $77 \%$ & $45 \%$ \\
\hline Literacy \& Academic skills & $90 \%$ & $59 \%$ & $76 \%$ & 4 \\
\hline Psychosocial well-being & $97 \%$ & $17 \%$ & $92 \%$ & $21 \%$ \\
\hline
\end{tabular}


following focus group excerpts: “... he may get discouraged, because of his communication - it is an obstacle between him and the other (hearing) children..." (participant mainly promoting spoken language); “... if teachers at schools for the Deaf are making use of Sign Language interpreters why can't the audiologist also make use of them? ... it would make it much easier for the child" (participant mainly promoting Sign Language). The importance of developing literacy skills and academic achievement were highlighted by the following excerpts from the focus group interviews: “... with subjects you must zoom-in individually, you must explain the terminology... because their vocabulary is poor, their world experiences are poor..." (participant mainly promoting spoken language); “...if they (the educational audiologists)...can overcome that bridge between Sign Language and written language, they will be worth their weight in gold..." (participant mainly promoting Sign Language).

\section{Psychosocial well-being}

Both sub-groups indicated the importance of intervention in developing the child's psychosocial well-being. In contrast, only a very small percentage specified a need for support in doing so. Emphasis on the development of psychological wellbeing can be seen in the following excerpts from the focus group interviews: “... he needs to have a solid foundation, because if he's not emotionally strong, he'll drop out..." (participant mainly promoting spoken language); “... ever so often he is embarrassed, because he didn't do his work or know what is going on, because he didn't hear... he will also feel lefi out from the Deaf Community..." (participant mainly promoting Sign Language).

Statistical analysis of the results regarding the educational management of hearing loss, revealed that some of the variables rendered chi-squared values greater than the critical value. Findings reveal that both sub-groups of participants who had diplomas, indicated a greater need for support in the development of language within activities of social interaction, than'participants with higher qualifications. Both sub-groups of participants who have received in-service training less frequently than once per month, indicated a greater need for support with articulation skills when planning speech production activities. Finally, both sub-groups of participants who have received in-service training less frequently than once per month, indicated a greater need for support in providing opportunities for socialising and expression in the classroom.

\section{DISCUSSION}

\section{Knowledge of educational audiology}

Participants' knowledge of educational audiology, as well as their need for support in the acquisition of this knowledge, is crucial in addressing the specific needs that may arise from the sensory impairment of children with hearing loss (Easterbrooks \& Radaszewski-Byrne, 1995; Flexer, 1993).

\section{Hearing Loss and the Negative Impact of a Hearing Loss}

Participants of both sub-groups strongly recommended that teachers have knowledge of the various aspects of hearing loss, as well as on the negative impact of a hearing loss on the various areas of development. In contrast, a smaller number of participants felt that teachers required support in the acquisition of knowledge in these two areas. These findings may indicate that participants generally did not realise the advantages of receiving support from a professional such as an educational audiologist (English, 1995; Johnson et al., 1997).

Furthermore, participants who mainly promote Sign Language indicated less need for the acquisition of knowledge and support in the various aspects of hearing loss as well as the various areas of impact relating to hearing loss than the other sub-group. The literature substantiates these findings, which can be explained by the differences in the communication instructional approaches followed by the two sub-groups (Lynas, 1994; Moores, 1996). Participants who mainly promote Sign Language were less interested in acquiring knowledge in the various aspects of hearing loss, such as the anatomy and functioning of the auditory mechanism, the aim and interpretation of an audiogram, the purpose and functioning of an FM system and hearing aid, et cetera. Reasons for their disinterest can be found in the education system. Participants who promote Sign Language often view knowledge in the aforementioned areas as approaching the hearing loss as a pathology, whereas they tend to regard hearing loss as a social identity and a sub-culture that does not necessarily have to be corrected (DEAFSA, 2001b; Lynas, 1994; Moores, 1996). Teachers who mainly promote Sign Language generally do not regard hearing loss as a condition that needs to be habilitated or which negatively influences all areas of development (DEAFSA, 2001b; Lynas, 1994; Moores, 1996). Furthermore, the acquisition of Sign Language is not negatively affected by the presence of a hearing loss (Moores, 1996).

\section{Maximising of Residual Hearing}

Participants of both sub-groups recommended that teachers have knowledge about the maximising of residual hearing. However very few participants indicated that teachers required support in the acquisition of this knowledge. This finding may imply that participants generally did not realise the importance of receiving support from a professional such as an educational audiologist when maximising a child's residual hearing (English, 1995; Johnson et al., 1997).

\section{Audiological and educational management of the child with a hearing loss}

Providing support to participants in the audiological and educational management of the child with hearing loss is essential in order to ensure that all facets of the child with hearing loss are developed (Sanders, 1988). Teachers should develop all the relevant areas in order to ensure that the child reaches his/her full potential as a scholar and a human being (Sanders, 1988). Information about the differences between the two sub-groups' need for support in the audiological and educational management of the child with hearing loss is crucial in order to plan for appropriate support structures in the inclusive education system.

\section{Speech Production Skills}

The majority of participants of both sub-groups recommended that teachers take various intervention steps and 
receive professional support in order to develop the speech production skills of the child with hearing loss. Results revealed that participants who mainly promote spoken language generally indicated a greater need for support in this development area than did participants who mainly promote Sign Language.

These findings are supported by the literature (Jamieson, 1994; Lynas, 1994; Moores, 1996; Paul \& Quigley, 1994; Sanders, 1988) and this, once again, relates to the differences in the communication instructional approaches followed by the two sub-groups. It is well known that teachers who mainly promote spoken language are primarily concerned with inter alia, the child's development of speech production skills in an oral environment or in inclusive settings as this is often a prerequisite for educational success (Jamieson, 1994; Paul \& Quigley, 1994; Sanders, 1988). On the other hand, teachers who mainly promote Sign Language tend to focus on the development of Sign Language skills, and the development of speech production skills is usually not a priority (Lynas, 1994; Moores, 1996). Therefore participants who mainly promote spoken language would indicate a greater need for support in the development of speech production skills.

More specifically, the results revealed that participants of both sub-groups strongly recommended professional support in order to acquire knowledge about various speech instructional approaches as well as support to subsequently apply the most suitable approach. These findings are confirmed by a recent study among South African teachers of children with hearing loss, which indicated that the majority of teachers experienced speech instruction as a difficult task, and that they felt incompetent in their ability to address deficits in speech production (Isaacson, 2000).

In addition, both sub-groups of participants recommended that teachers monitor changes in speech intelligibility. Changes in the quality of articulation, voice, pitch, et cetera, should be monitored, in order to target the appropriate sounds that the child with hearing loss is learning to pronounce correctly (Froehlinger \& Bryant, 1981). However, results indicated that only a small number of participants in both sub-groups recommended professional support in order to monitor changes in the child's speech intelligibility. These findings may indicate that participants were of the opinion that they had sufficient skills in this area. A study among South African teachers found, however, that teachers often neglected to monitor the changes in speech intelligibility and rarely completed phonetic inventories for each child (Isaacson, 2000). The fact that participants did not indicate a need for support in this area cannot be seen to indicate that they hadsufficient skills.

For these reasons, educational audiologists should promote more awareness regarding the development of speech production skills. Together with speech-language therapists, they are the most suitable professionals to offer the teachers support in the areas of speech assessment and intervention (English, 1995; Johnson et al., 1997; Sanders, 1988). In order to address speech deficits in children with hearing loss, the teacher will need essential information on the child's phonological repertoire, as well as audiological information such as the type and degree of hearing loss, response with amplification, speech discrimination performance, listening skills, and the child's speechreading skills (Johnson et al., 1997). The educational audio- logist should provide varying degrees of support in the development of speech production skills that will depend on the communication instructional approach followed by the teacher.

\section{Language, Communication, Literacy, Academic Skills and Psychosocial well-being}

Participants of both sub-groups strongly recommended that teachers take various intervention steps in order to develop language skills, communication skills, literacy skills, academic achievement and psychosocial well-being in children with hearing loss. In contrast, participants of both sub-groups indicated that they required only an average to below-average amount of support in the development of these skills. Participants' failure to recommend support proportional to the intervention steps, may indicate that they did not realise the benefits of receiving support from a professional such as an educational audiologist in developing the language, communication and literacy skills, and in the academic achievement and psychosocial well-being of the child with a hearing loss (English, 1995; Johnson et al., 1997).

It is evident that educational audiologists need to advocate the range of their services to teachers, and the benefits of receiving this support in educating children with hearing loss in the inclusive educational setting. Teamwork and support should be implemented in schools to benefit the whole of the educational team. It should clearly be demonstrated that the services of educational audiologists are for all teachers and children with hearing loss, regardless of the communication instructional approach followed.

\section{CONCLUSION}

Results indicated various needs of teachers of children with hearing loss as well as differences between the two subgroups of participants' need for support in various areas. Determining these differences is crucial in order to plan for appropriate service delivery that will benefit teachers of both sub-groups and ultimately ensure that the child with hearing loss develops his/her full potential.

This study indicated a definite lack of knowledge among teachers with regard to educational audiology principles' in spite of their in-service training. It becomes clear that teachers require further training and professional support in the development of auditory, language, speech, communicatiọn, literacy, academic, and psychosocial skills (Johnson et al., 1997) in order to deliver appropriate and effective services to children with hearing loss in the inclusive education system. South Africa consists of a unique combination of developed and developing contexts, and this limits the relevance of educational audiology service delivery models applied in developed countries such as the USA and European countries (Fair \& Louw, 1999). Adaptations to the services delivered by educational audiologists should be made to overcome specific South African problems and issues. These problems and issues include overcrowded classrooms and limited staff resources, the lack of parental involvement, the absence of adequate financial resources, increasing poverty, the rising HIV/AIDS pandemic, and challenges associated with diversity in culture and language (Penn \& Reagan, 1995; Viljoen \& Molefe; 2001).

The Literature confirms the importance of teachers 
receiving the support of an educational audiologist when including the child with a hearing loss. Educational audiologists are specialists in the field of hearing loss and the impact of hearing loss on a child's ability to be educated among hearing peers (English, 1995; Johnson et al., 1997). Furthermore, the educational audiologist assumes the role of family and community liaison agent which considers the child as a unique human being within his/her social context, and therefore links the child's significant others to the educational team, in order to ensure the applicability of the child's intervention programme, thereby increasing the success of outcomes (Johnson et al., 1997).

Only by working together as a team can the successful inclusion of children with hearing loss be achieved in South Africa. As part of this team, the educational audiologist and his/her services to children with hearing loss, should be recognised: "Audiologists, as professionals who are experts in the management of hearing in an educational setting, can have an enormous impact on the future of children with all types and degrees of hearing problems. Indeed, thorough and insightful audiologic management can make the difference between one child with hearing loss becoming an independent, contributing citizen and another child living life on the fringe" (Flexer, 1993 p.204).

\section{ACKNOWLEDGEMENTS}

This article is based on a doctoral thesis entitled "An educational audiology service delivery model: Needs of teachers of children with hearing loss", written by the first author in partial fulfillment of the requirements for a D Phil degree in Communication Pathology at the University of Pretoria, South Africa under the promotership of: Prof: R. Hugo and the co-promotorship of Prof B. Louw.

\section{REFERENCES}

American Speech-Language-Hearing Association. (1993). Guidelines for audiology services in the schools. Asha, 35, (10), 24-32.

Berg, B.L. (1998). Qualitative research methods for the social sciences (3rd ed.). Boston: Allyn \& Bacon.

Berg, FS., Blair, J.C., \& Benson, P.V. (1996). Classroom acoustics: The problem, impact and solution. Language, Speech, and Hearing Services in Schools, 27(1), 16-20.

Bless, C., \& Higson-Smith, C. (1995). Fundamentals of social research methods: An African perspective ( $2 \mathrm{nd} \mathrm{ed}$.). Cape Town: Juta.

Brackett, D. (1997). Intervention for children with hearing impairment in general education settings. Language, Speech, and Hearing Services in Schools, 28(4), 355-361.

Bunch, G.O. (1987). The curriculum and the hearing-impaired student: Theoretical and practical considerations. Boston: College-Hill.

Crandell, C.C., \& Smaldino, J.J. (2000). Current practices in classroom sound field FM amplification. Journal of Educational Audiology, 8, 1-11.

DEAFSA. (2001a). Contacts: Schools for the Deaf. Retrieved April 4, 2001 from http://www.deafsa.co.za/contact.htm .

DEAFSA. (2001b). About: Deaf culture. Retrieved January 11,
2002 from http://www.deafsa.co.za/about/culturel.htm .

Easterbrooks, S., \& Radaszewski-Byrne, M. (1995). The development of knowledge and skill statements for teachers of students who are deaf or hard of hearing. Joumal of Childhood Communication Disorders, 17(1), 20-26.

Education White Paper no 6. (2001). Special needs education: Building an inclusive education and training system. Pretoria, South Africa: Department of Education.

English, K.M. (1995). Educational audiology across the lifespan: Serving all leamers with hearing impairment. Baltimore: Paul H Brookes.

Fair, L., \& Louw, B. (1999). Early communication intervention within a community-based intervention model in South Africa. The South African Joumal of Communication Disorders, 46, 13-23.

Flexer, C. (1993). Management of hearing in an educational setting. In J.G. Alpiner \& P.A. McCarthy (Eds.) Rehabilitative audiology: Children and adults (2nd ed.). Baltimore: Williams \& Wilkins.

Froehlinger, V.J., \& Bryant, R.W. (1981). Mainstreaming the hearing impaired child: Language and Reading. In V.J. Froehlinger (Ed.), Today's hearing-Impaired child: Into the mainstream of education: A practical guide for preschool and elementary teachers, parents, and administrators. (pp 159-188) Washington: Alexander Graham Bell Association for the Deaf.

Huysamen, G.K. (1998). Descriptive statistics for the social and behavioural sciences (3rd ed.). Pretoria: Van Schaik.

Isaacson, Z. (2000). A Speech programme for deaf learners to be used in the classmom by teachers. Unpublished doctoral dissertation, University of Pretoria, Gauteng, South Africa.

Jamieson, J.R. (1994). The impact of hearing impairment. In J. Katz (Ed.), Handbook of Clinical Audiology (4th ed.). Baltimore: Williams \& Wilkins.

Johnson, C.D., Benson, P.V., \& Seaton, J.B. (1997). Educational Audiology Handbook. San Diego: Singular.

Keith, K., \& Ross, E. (1998). Attitudes of a group primary school teachers towards the educational inclusion of hearing-impaired learners in regular classrooms. The South African Journal of Communication Disorders, 45, 39-50.

Leedy, P.D., \& Ormrod, J.E. (2001). Practical research: Planning and design. New Jersey: Merril.

Lynas, W. (1994). Communication options in the education of deaf children. San Diego: Singular.

McAnally, P.L., Rose, S., \& Quigley, S.P. (1987). Language learning practices with deaf children. Boston: CollegeHill.

Moores, D.F. (1996). Educating the deaf: Psychology, principles, and practices. Boston: Houghton Miffflin.

Morgan, D.L. (1997). Focus groups as qualitative research (2nd ed.). London: SAGE.

Mouton, J., \& Marais, H.C. (1996). Basic concepts in the methodology of the social sciences (5th ed.). Pretoria: HSRC.

Neuman, W.L. (1997). Social research methods: Qualitative and quantitative approaches (3rd ed.). Boston: Allyn \& Bacon. 
Paul, P.V., \& Quigley, S.P. (1994). Language and deafness (2nd ed.). San Diego: Singular.

Penn, C., \& Reagan, T. (1995). On the other hand: Implications of the study of South African Sign Language for the education of the Deaf in South Africa. South African Journal of Education, 15(2), 92-96.

Reid, A., \& Gough, S. (2000). Guidelines for reporting and evaluating qualitative research: What are the alternatives? Environmental Education Research, 6(1), 59-90.

Sanders, D.M. (1988). Teaching deaf children: Techniques and methods. Boston: College-Hill.

Schurink, E.M. (1998). Designing qualitative research. In A.S. de Vos (Ed.), Research at grass roots: A primer for the caring professions. (pp 252-263) Pretoria: Van Schaik.
Stewart, D.W., \& Shamdasani, P.N. (1990). Focus groups: Theory and practice. London: SAGE.

Strydom, H. (2002). Ethical aspects of research. In A.S. de Vos (Ed.), Research at grass roots: For the social sciences and human services professions (2nd ed.). (pp 23-36) Pretoria: Van Schaik.

Viljoen, C.F., \& Molefe, R.M.L. (2001). Language related problems of limited English proficiency leamers in Grade 1. South African Joumal of Education, 21(2), 121-127.

Webster, A., \& Wood, D. (1989). Special needs in ordinary schools: Children with hearing difficulties. London: Cassell.

\section{APPENDIX A}

List of schools that provide for children with hearing loss in South Africa $(n=35)$

\begin{tabular}{|c|c|}
\hline Eastern Cape & Efata School for the Blind and Deaf \\
\hline & Greenwood Primary School \\
\hline & Reubin Birin School for the Hearing Impaired \\
\hline & St Thomas School for the Deaf \\
\hline \multirow[t]{2}{*}{ Free State } & Bartimea School for the Deaf and Blind \\
\hline & Thiboloha School for the Deaf and Blind \\
\hline \multirow[t]{8}{*}{ Gauteng } & Dominican School for the Deaf \\
\hline & Filadelfia Secondary School \\
\hline & Katlehong School for the Hearing Impaired \\
\hline & MC Kharbai School for the Deaf \\
\hline & Sizwile School for the Deaf \\
\hline & Sonitus School for the Hard of Hearing \\
\hline & St Vincent School for the Deaf \\
\hline & Transoranje School for the Deaf \\
\hline \multirow[t]{8}{*}{ Kwazulu-Natal } & Durban School for the Hearing Impaired \\
\hline & Fulton School for the Deaf \\
\hline & Indaleni School for the Deaf \\
\hline & Kwa Thintwa School for the Deaf \\
\hline & Kwa Vulindlebe School for the Deaf \\
\hline & St Martin de Porres Comprehensive School \\
\hline & VN Naik School for the Deaf \\
\hline & Vuleka School for the Deaf \\
\hline \multirow[t]{4}{*}{ Limpopo } & Bosele School for the Blind and Deaf \\
\hline & Nelsonskop Centre for the Hearing Impaired \\
\hline & Tshilidzini School for the Deaf \\
\hline & Yingisani School for the Deaf \\
\hline Mpumalanga & Silindokuhle School for the Mentally Retarded, Blind and Deaf \\
\hline Northern Cape & No schools to date \\
\hline \multirow[t]{2}{*}{ North West } & North West Secondary School \\
\hline & Kutlwanong School for the Deaf \\
\hline \multirow[t]{6}{*}{ Western Cape } & De la Bat School \\
\hline & Dominican Grimley School for Deaf Children \\
\hline & Dominican School for Deaf Children \\
\hline & Mary Kihn School for Partially Hearing Pupils \\
\hline & Noluthando Institute for the Deaf \\
\hline & Nuwe Hoop Centre for the Hearing Impaired \\
\hline
\end{tabular}




\section{APPENDIX B}

\section{Dear teacher, please}

- Complete all the questions

- Share your knowledge and opinions in detail

- Place a cross in the appropriate block

- More than one block may be crossed where appropriate

- All responses will remain highly confidential

- Any identifying information will be removed from the final report

\section{SECTION A: TEACHER INFORMATION}

1. What is your gender?

\begin{tabular}{|c|c|}
\hline male & fernale \\
\hline
\end{tabular}

2. What is your age?

\begin{tabular}{|l|l|l|l|}
\hline $20-30$ years & $31-40$ years & $41-50$ years & 51 years and older \\
\hline
\end{tabular}

3. What is your home language?

\begin{tabular}{|l|l|l|l|l|l|l|}
\hline Afrikaans & English & Sotho & Zulu & Xhosa & Sign language & Other Specify: \\
\hline
\end{tabular}

4. What is the highest educational qualification you have obtained?

5. Have you had any special training in working with children with hearing loss?

\begin{tabular}{|c|c|}
\hline yes & no \\
\hline
\end{tabular}

5.1 If YES, please specify your training:

\begin{tabular}{|l|l|l|}
\hline in-service training & special diploma/certificate & special degree \\
\hline
\end{tabular}

6. Approximately how long have you been involved with children with hearing loss?

\begin{tabular}{|l|c|c|c|}
\hline $0-1$ years & $2-3$ years & $4-5$ years & more than 5 years \\
\hline
\end{tabular}

\section{SECTION B: INFORMATION REGARDING TEACHING PRACTICES}

7. Which phases do you teach?

\begin{tabular}{|c|c|c|c|c|}
\hline pre-school & foundation & intermediate & senior & vocational/ \\
& Gr R-Gr 3 & Gr 4-Gr 6 & Gr 7-Gr 12 & technical \\
\hline
\end{tabular}

8. What is the total number of learners you teach?

\begin{tabular}{|c|c|c|c|c|l|}
\hline $\begin{array}{c}0-10 \\
\text { learners }\end{array}$ & $\begin{array}{c}11-20 \\
\text { learners }\end{array}$ & $\begin{array}{c}21-30 \\
\text { learners }\end{array}$ & $\begin{array}{c}31-40 \\
\text { learners }\end{array}$ & $\begin{array}{c}41-50 \\
\text { learners }\end{array}$ & $\begin{array}{l}\text { more than } \\
50 \text { learners }\end{array}$ \\
\hline
\end{tabular}

9. What medium of language instruction do you use at your school?

\begin{tabular}{|l|l|l|l|l|l|l|}
\hline Afrikaans & English & Sotho & Zulu & Xhosa & Sign language & Other Specify: \\
\hline
\end{tabular}

10. What method of communication do you use with your learners?

\begin{tabular}{|c|c|c|c|}
\hline Oral-Aural & Sign language & Total Communication & Bilingual/Bicultural \\
\cline { 3 - 3 } &
\end{tabular}


11. Have teachers at your school received any specific in-service training in terms of managing the child with a hearing loss? (e.g. any workshops, seminars, hands-on demonstrations)

\begin{tabular}{|c|c|}
\hline yes & no \\
\hline
\end{tabular}

11.1 If YES, indicate how often training takes place:

\begin{tabular}{|c|c|c|c|c|}
\hline every 2 years & annually & every six months & every three months & every month \\
\hline
\end{tabular}

12. Do you think in-service training benefits you?

\begin{tabular}{|c|c|}
\hline yes & no \\
\hline
\end{tabular}

Explain your answer:

\section{SECTION C: THE TEACHER IN THE FUTURE INCLUSIVE EDUCATIONAL SYSTEM}

\section{Dear teacher, please}

- The following questions require your opinion on:

what you think the skill of a teacher of children with hearing loss in the future inclusive educational system should

be, and whether you think the teacher will require support from a professional person who is knowledgeable in

these areas

- Remember you can tick more than one answer where appropriate

\section{KNOWLEDGE OF THE CHILD WITH HEARING LOSS}

13. In which of the following areas should a teacher in an inclusive educational system have basic knowledge and support in?

Please tick off your choices in both columns 囚:

\begin{tabular}{|c|c|c|}
\hline & knowledge thereof & to obtain this knowledge \\
\hline Understand the process of communication interaction & & $!$ \\
\hline $\begin{array}{l}\text { Know about the different communication options available, namely } \\
\text { Oral-Aural, Sign language, Total Communication and the } \\
\text { Bilingual/Bicultural method }\end{array}$ & & 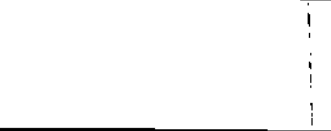 \\
\hline Know the structure and working of the ear & & 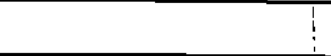 \\
\hline Be able to interpret a child's audiogram (hearing graph) & & $\bar{i}$ \\
\hline Know the purpose and working of an FM system & & \\
\hline Know the purpose and working of a hearing aid & & \\
\hline Know how to inspect a hearing aid and detect the problem when it is not wo & & \\
\hline Know the common causes of hearing loss & & \\
\hline Know the types of hearing loss associated with these common causes & & \\
\hline Know the factors that can further damage hearing & & \\
\hline Know the impact a hearing loss will have on a child's ability to be educated & & 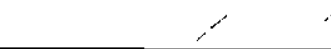 \\
\hline None of the above-mentioned & & \\
\hline
\end{tabular}


14. A teacher in an inclusive educational system should know that hearing loss can impact negatively on the following areas of the child and he/she will require support in the following areas:

Please tick off your choices in both columns $\bowtie:$

\begin{tabular}{|l|c|}
\hline \begin{tabular}{c} 
Teacher should know $\begin{array}{c}\text { a hearing loss can } \\
\text { negatively impact on } \\
\text { this area }\end{array}$ \\
\hline
\end{tabular} & $\begin{array}{c}\text { Teacher requires support } \\
\text { to obtain knowledge on } \\
\text { the negative impact } \\
\text { of the hearing loss } \\
\text { on this area }\end{array}$ \\
\hline & \\
\hline & \\
\hline & \\
\hline & \\
\hline
\end{tabular}

15. If a child in an inclusive class has been identified with a hearing loss, the teacher should have knowledge of the following in order to enhance the child's ability to hear and he/she will require support in the following areas:

Please tick off your choices in both columns $\mathbf{\text { : }}$

\begin{tabular}{|c|c|c|}
\hline & $\begin{array}{l}\text { have basic } \\
\text { knowledge thereof }\end{array}$ & $\begin{array}{l}\text { Irom a protessional } \\
\text { to obtain this knowledge }\end{array}$ \\
\hline Identify noise levels inside and outside the classroom. & & \\
\hline \multicolumn{3}{|l|}{ Try to reduce noise levels inside and outside the classroom } \\
\hline $\begin{array}{l}\text { Suggest to the relevant authorities at school that the classroom should have more } \\
\text { absorbent surfaces such as carpets and curtains to enhance the sound quality } \\
\text { in the classroom }\end{array}$ & . & \\
\hline \multicolumn{3}{|l|}{$\begin{array}{l}\text { Suggest to the relevant authorities at school that the child could benefit } \\
\text { from the use of an FM system in class }\end{array}$} \\
\hline \multicolumn{3}{|l|}{ Encourage the child to wear his/her hearing aids at all times } \\
\hline \multicolumn{3}{|l|}{ Teach the child the correct listening behaviour in class } \\
\hline \multicolumn{3}{|l|}{ Teach the child speech-reading (lip-reading) skills } \\
\hline None of the above-mentioned & & \\
\hline
\end{tabular}

\section{LANGUAGE OF THE CHILD WTTH HEARING LOSS}

14. Which of the following steps should a teacher in an inclusive educational system have to take in order to address a child's delayed language skills (due to hearing loss) and in which of the following areas will he/she require support?

Please tick off your choices in both columns $\otimes:$

Use the hierarchy of normal language development to plan activities for language development

Take into account the child's unique level of language functioning when talking to the child

Take into account the child's unique level of language functioning when planning the content of teaching material

Modify and/or adapt teaching materials, teaching techniques, and the classroom environment to meet the language needs of the child

Have knowledge of different language instructional approaches such as: Fitzgerald Key, Natural approach, etc. and apply the best suited approach for the child

Emphasise language across all contexts in the school

Practise language within activities of social interaction

Take into account that some children may have additional language problems such as: phonological processes, second language confusion, etc. that need to be addressed None of the above-mentioned 


\section{SPEECH OF THE CHILD WITH HEARING LOSS}

17. Which of the following steps should a teacher in an inclusive educational system have to take in order to address a child's deficits in speech production (due to hearing loss) and in which of the following areas will he/she require support?

Please tick off your choices in both columns 区

Use the hierarchy of normal speech development to plan activities for improvement of speech intelligibility

Take into account the child's unique physical ability to produce sounds with his/her mouth when planning activities for improvement of speech intelligibility Obtain information on the child's ability to pronounce all the sounds

Monitor and document changes in the faulty sounds that the child is learning to pronounce correctly

Have knowledge of different speech instructional approaches such as: analytical, whole, formal, multisensory, etc. and apply the approach best suited for the child

Take into account that some children may have additional speech problems such as: stuttering, voice problems, etc. that need to be addressed

None of the above-mentioned

\section{COMMUNICATION OF THE CHILD WITH HEARING LOSS}

18. Which of the following steps should a teacher in an inclusive educational system have to take in order to address a child's communication difficulties (due to hearing loss) and in which of the following areas will he/she require support?

Please tick off your choices in both columns $\otimes:$ communicate and can develop his/her communication skills

Apply communication repair strategies when communication breakdowns occur in class

Have knowledge of the communication options available to the child, either the Oral-Aural, Sign language, Total Communication or Bilingual/Bicultural method

Use one of the above-mentioned communication options in class

None of the above-mentioned

\section{LITERACY SKILLS OF THE CHILD WITH HEARING LOSS}

19. Which of the following steps should a teacher in an inclusive educational system have to take in order to address a child's poor literacy skills (due to hearing loss) and in which of the following areas will he/she require support?

Please tick off your choices in both columns $\otimes:$

Ensure that the child has acquired the basics of language before proceeding with literacy instruction

Identify the origin of the reading and writing errors made by the child, such as auditory discrimination problems, language problems, etc

Address the origin of the reading and writing errors made by the child

Have knowledge of different literacy instructional approaches such as: top-down or bottom-up, etc. and apply the best suited approach for the child

None of the above-mentioned

\begin{tabular}{|l|l|}
\hline $\begin{array}{c}\text { Teacher should take } \\
\text { these steps }\end{array}$ & $\begin{array}{c}\text { Teacher requires support } \\
\text { from a professional } \\
\text { to execute these steps }\end{array}$ \\
\hline & \\
\hline & \\
\hline & \\
\hline & \\
\hline & \\
\hline
\end{tabular}




\section{ACADEMIC ACHIEVEMENT OF THE CHILD WITH HEARING LOSS}

20. Which of the following steps should a teacher in an inclusive educational system have to take in order to address a child's poor academic achievement (due to hearing loss) and in which of the following areas will he/she require support?

Please tick off your choices in both column 区

\begin{tabular}{|c|c|c|}
\hline Please hick oly your & these steps & $\begin{array}{l}\text { Teacher requires support } \\
\text { from a professional } \\
\text { to execute these steps }\end{array}$ \\
\hline $\begin{array}{l}\text { Tailor the child's learning experience to his/her cognitive, physical, } \\
\text { socio-emotional, and cultural level }\end{array}$ & & \\
\hline Modify the curriculum of the subject by controlling the vocabulary and syntax & & \\
\hline None of the above-mentioned & & \\
\hline
\end{tabular}

\section{PSYCHOSOCLAL DEVELOPMENT OF THE CHILD WITH HEARING LOSS}

21. Which of the following steps should a teacher in an inclusive educational system have to take in order to address a child's troublesome psychosocial development (due to hearing loss) and in which of the following areas will he/she require support?

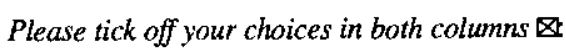

\begin{tabular}{|l|l|l|}
\cline { 2 - 3 } & $\begin{array}{c}\text { Teacher should take } \\
\text { these steps }\end{array}$ & $\begin{array}{c}\text { Teacher requires support } \\
\text { from a professional } \\
\text { to execute these steps }\end{array}$ \\
\hline & & \\
\hline & & \\
\hline
\end{tabular}

\section{SERVICE DELIVERY AND THE CHILD WITH HEARING LOSS}

22. Which of the following persons should a teacher in an inclusive educational system involve during teamwork in order to successfully plan the child's educational programme?

Please tick off your choices in the column $\otimes$

Teacher will need these person(s) on the team

\begin{tabular}{|l|l|}
\hline The child with hearing loss & \\
\hline The parents & \\
\hline The speech therapist $\quad$ & \\
\hline The hearing therapist (audiologist) & \\
\hline The social worker & \\
\hline The psychologist & \\
\hline The occupational therapist & \\
\hline Others, specify: & \\
\hline None of the above-mentioned & \\
\hline
\end{tabular}


23. Which $O N E$ of these persons will you choose to co-ordinate the team and to liaise with other team members in order to assist the teacher of a child with hearing loss?

Please tick off ONE choice in the column $\otimes$ :

\begin{tabular}{|l|l|}
\hline The child with hearing loss & \\
\hline The parents & \\
\hline The teacher must do it himself/herself & \\
\hline The hearing therapist (audiologist) & \\
\hline The speech therapist & \\
\hline The social worker & \\
\hline The psychologist & \\
\hline The occupational therapist & \\
\hline None of the above-mentioned & \\
\hline
\end{tabular}

24. If a professional who specialises in children with hearing loss can provide support to the teacher in the inclusive education system, which of the following methods of support will benefit the teacher?

Please tick off your choices in the column $\otimes$ :

\begin{tabular}{|l|l|}
\hline A once-off training session & method(s) of support \\
\hline Regular workshops & \\
\hline Continuous in-service training & \\
\hline Hands-on assistance when needed & \\
\hline None of the above-mentioned & \\
\hline
\end{tabular}

25. If a professional who specialises in children with hearing loss can provide support to the teacher in an mclusive educational system, which ONE of these service delivery models would you recommend?

Please tick off ONE choice in the column区:

\begin{tabular}{|l|l|}
\hline $\begin{array}{l}\text { The school employs one full-time professional to conduct services at the school } \\
\text { The school utilises a private professional from outside the school to conduct part-time services } \\
\text { at the school }\end{array}$ & \\
\hline $\begin{array}{l}\text { The school employs one full-time professional who receives part-time assistance from another } \\
\text { private professional in order to conduct services at the school }\end{array}$ & \\
\hline None of the above-mentioned. Specify your own suggestion: & Dear teacher, provide detailed explanations of your answers \\
\hline
\end{tabular}

27. Do you feel that the teacher in an inclusive educational system can benefit from the support of a hearing therapist (audiologist)?

\begin{tabular}{|l|l|}
\hline yes & no \\
\hline
\end{tabular}

27.1 Explain your answer: 
28. What is the biggest challenge that may face a teacher of children with hearing loss in an inclusive educational system?

29. What possible solution(s) can you suggest for the above-mentioned challenge?

30. Do you think that children with hearing loss will benefit from the future inclusive educational system?

\begin{tabular}{|l|l|}
\hline yes & no \\
\hline
\end{tabular}

31. Explain your answer:

Thank you for your time and your valuable contribution towards this research project! 
APPENDHX C

Development and description of questionnaire content

\begin{tabular}{|c|c|c|c|}
\hline SECTION & QUESTIONS & TOPIC & JUSTHFICATION \\
\hline $\begin{array}{l}\text { Section A: } \\
\text { Five close-ended } \\
\text { questions \& } 1 \\
\text { open-ended } \\
\text { question }\end{array}$ & $\begin{array}{l}\text { Questions } \\
1 \text { to } 6\end{array}$ & $\begin{array}{l}\text { Biographic information } \\
\text { of participants }\end{array}$ & $\begin{array}{l}\text { Questions were included on participants' personal characteristics such as: } \\
\text { gender; age; home language; qualifications; specialised training; and } \\
\text { experience in order to describe the participants included in the study, as } \\
\text { well as to draw correlations during data analysis. }\end{array}$ \\
\hline $\begin{array}{l}\text { Section B: } \\
\text { Seven close- } \\
\text { ended questions } \\
\& 1 \text { open-ended } \\
\text { question }\end{array}$ & $\begin{array}{l}\text { Questions } \\
7 \text { to } 12\end{array}$ & $\begin{array}{l}\text { Information regarding } \\
\text { teaching practices }\end{array}$ & $\begin{array}{l}\text { Questions requested information with regards to teaching practices and } \\
\text { included: the educational phases taught; number of learners; medium of } \\
\text { language instruction; method of communication instruction; and in-service } \\
\text { training in order to describe the schools included in the study, as well as to } \\
\text { draw comparisons during data analysis. }\end{array}$ \\
\hline \multirow[t]{6}{*}{$\begin{array}{l}\text { Section C: } \\
\text { Fifteen close- } \\
\text { ended questions } \\
\& 5 \text { open-ended } \\
\text { questions }\end{array}$} & Question 13 & $\begin{array}{l}\text { Knowledge of the various } \\
\text { aspects of hearing loss and } \\
\text { the need for support }\end{array}$ & $\begin{array}{l}\text { To determine whether participants realised the importance of having } \\
\text { knowledge in these areas, in order to successfully educate children with } \\
\text { hearing loss in the inclusive educational system. In this question provision } \\
\text { was also made for determining participants' need for support in order to } \\
\text { acquire this knowledge, as teachers will benefit from the support of an } \\
\text { educational audiologist in order to acquire knowledge of the child with a } \\
\text { hearing loss (Johnson, Benson \& Seaton, 1997). }\end{array}$ \\
\hline & Question 14 & $\begin{array}{l}\text { Knowledge of the areas that } \\
\text { hearing loss impacts on and } \\
\text { the need for support }\end{array}$ & $\begin{array}{l}\text { To determine whether participants had knowledge of all the areas that } \\
\text { hearing loss impacted on. Participants' need for support in obtaining know- } \\
\text { ledge in order to be able to address the negative impact of the hearing loss } \\
\text { was also probed in this question. Teachers may benefit from the support of } \\
\text { an educational audiologist in addressing the negative impact of the hearing } \\
\text { loss on the child's ability to be educated (Johnson, Benson \& Seaton, } \\
\text { 1997). } \\
\text { The following items were included: language development; speech produc- } \\
\text { tion; communication skills; literacy skills; academic achievement; and } \\
\text { psychosocial development. These areas English (1995); Johnson, Benson } \\
\text { \& Seaton (1997); Moores (1996); and Sanders (1988) could be negatively } \\
\text { impacted by a hearing loss. }\end{array}$ \\
\hline & Question 15 & $\begin{array}{l}\text { Knowledge of the steps to } \\
\text { be taken in order to develop } \\
\text { the child's residual hearing } \\
\text { and the need for support to } \\
\text { obtain this knowledge }\end{array}$ & $\begin{array}{l}\text { To determine whether participants had knowledge of all the steps required to } \\
\text { optimally develop the child's residual hearing. Participants' need for support } \\
\text { in order to obtain knowledge on how to develop a child's residual hearing } \\
\text { was also included, because teachers may benefit from the support of an } \\
\text { educational audiologist in this regard. (Johnson, Benson \& Seaton, 1997). }\end{array}$ \\
\hline & Question 16 & $\begin{array}{l}\text { Knowledge of the steps to } \\
\text { be taken in order to develop } \\
\text { the child's language skills } \\
\text { and the need for support }\end{array}$ & $\begin{array}{l}\text { To determine whether participants had knowledge of all the steps required } \\
\text { to develop the child's language skills. Participants' need for support in } \\
\text { order to develop the child's language skills, was also included. }\end{array}$ \\
\hline & Question 17 & $\begin{array}{l}\text { Knowledge of the steps to } \\
\text { be taken in order to develop } \\
\text { the child's speech produc- } \\
\text { tion skills and the need for } \\
\text { support }\end{array}$ & $\begin{array}{l}\text { To determine whether participants had knowledge of all the steps required } \\
\text { to develop the child's speech production skills. Participants' need for } \\
\text { support, in order to develop the child's speech production skills, was also } \\
\text { included. }\end{array}$ \\
\hline & Question 18 & $\begin{array}{l}\text { Knowledge of the steps to } \\
\text { be taken in order to develop } \\
\text { the child's communication } \\
\text { skills and the need for } \\
\text { support }\end{array}$ & $\begin{array}{l}\text { To determine whether participants had knowledge of all the steps required } \\
\text { to develop the child's communication skills. Participants' need for support } \\
\text { in order to develop the child's communication skills was also included. }\end{array}$ \\
\hline \multirow[t]{2}{*}{$\cdot$} & Question 19 & $\begin{array}{l}\text { Knowledge of the steps to } \\
\text { be taken in order to develop } \\
\text { the child's literacy skills and } \\
\text { the need for support }\end{array}$ & $\begin{array}{l}\text { To determine whether participants had knowledge of all the steps required } \\
\text { to develop the child's literacy skills. Participants' need for support, in order } \\
\text { to develop the child's literacy skills, was also included. }\end{array}$ \\
\hline & Question 20 & $\begin{array}{l}\text { Knowledge of the steps to } \\
\text { be taken in order to promote } \\
\text { the child's academic } \\
\text { achievement and the need } \\
\text { for support }\end{array}$ & $\begin{array}{l}\text { To determine whether participants had knowledge of all the steps required } \\
\text { to promote the child's academic achievement. Participants' need for } \\
\text { support in order to promote the child's academic achievement was also } \\
\text { included in this question. This was included. }\end{array}$ \\
\hline
\end{tabular}




\begin{tabular}{|c|c|c|c|}
\hline \multicolumn{4}{|c|}{$\begin{array}{l}\text { APPENDIX C } \\
\text { continued }\end{array}$} \\
\hline \multirow[t]{3}{*}{ SECTION } & QUESTIONS & TOPIC & JUSTIFICATION \\
\hline & Question 21 & $\begin{array}{l}\text { Knowledge of the steps to } \\
\text { be taken in order to develop } \\
\text { the child's psychosocial } \\
\text { well-being and the need for } \\
\text { support }\end{array}$ & $\begin{array}{l}\text { To determine whether participants had knowledge of all the steps required } \\
\text { to develop the child's well-being. Participants' need for support, in order } \\
\text { to develop the child's psychosocial well-being was also included. }\end{array}$ \\
\hline & Question 22 & $\begin{array}{l}\text { Information on the selection } \\
\text { of relevant team members } \\
\text { for the inclusive educational } \\
\text { system }\end{array}$ & $\begin{array}{l}\text { To determine which team members participants wanted to include during } \\
\text { teamwork in the inclusive educational system. The following items were } \\
\text { included: the child with hearing loss; the parents; the speech therapist; the } \\
\text { educational audiologist; the social worker; the psychologist; the occupa- } \\
\text { tional therapist; and an option to add a person not mentioned. Working with } \\
\text { other team members is as crucial part in the success of educating the child } \\
\text { with a hearing loss (Johnson, Benson \& Seaton, 1997). Literature suggests } \\
\text { that of all the team members involved, the child with a hearing loss, and } \\
\text { the parents/guardians should always be involved (English, 1995). }\end{array}$ \\
\hline & Question 23 & $\begin{array}{l}\text { Information on the selection } \\
\text { of a team co-ordinator for } \\
\text { teamwork in the inclusive } \\
\text { educational system }\end{array}$ & $\begin{array}{l}\text { To determine participants' opinions on which person they thought should } \\
\text { fulfil the role of team co-ordinator during teamwork in the inclusive } \\
\text { educational system. } \\
\text { The following items were included: the child with hearing loss; the } \\
\text { parents; the teacher; the educational audiologist; the speech therapist; the } \\
\text { social worker; the psychologist; or the occupational therapist. According } \\
\text { to literature, any of these persons, except the child, can function as a team } \\
\text { co-ordinator (English, } 1995 \text { and Benson \& Seaton, 1997): }\end{array}$ \\
\hline & Question 24 & $\begin{array}{l}\text { Information on the selection } \\
\text { of methods available for } \\
\text { teacher support in the } \\
\text { inclusive educational system }\end{array}$ & $\begin{array}{l}\text { To determine participants' opinions on what methods of support they } \\
\text { thought could benefit teachers in the inclusive educational system. } \\
\text { The following items were included: once-off training session; regular } \\
\text { workshops; continuous in-service training; and hands-on assistance when } \\
\text { needed. All of these methods of support have their benefits, but, arguably, } \\
\text { continuous in-service training may provide the most benefit to teachers, } \\
\text { due to the higher frequency of such training sessions (English, 1995). }\end{array}$ \\
\hline & Question 25 & $\begin{array}{l}\text { Information on the selection } \\
\text { of an educational audiology } \\
\text { service delivery model for } \\
\text { use within the inclusive } \\
\text { educational system }\end{array}$ & $\begin{array}{l}\text { To determine participants' opinions on what educational audiology service } \\
\text { delivery model they thought could benefit teachers in the inclusive } \\
\text { educational system. } \\
\text { The following items were included: the school-based system; the } \\
\text { contractual agreement system; and a combination of the two systems. } \\
\text { These three options were identified as the main educational audiology } \\
\text { service delivery systems found in school settings, and were therefore } \\
\text { included (Johnson, Benson \& Seaton, 1997). }\end{array}$ \\
\hline & Question 26 & $\begin{array}{l}\text { Knowledge of the functions } \\
\text { of an educational } \\
\text { audiologist }\end{array}$ & $\begin{array}{l}\text { To determine (1) whether participants had knowledge of the roles and } \\
\text { responsibilities of the educational audiologist in the school setting; (2) to } \\
\text { determine participants' opinions on what they thought the roles and } \\
\text { responsibilities of the educational audiologist within the inclusive } \\
\text { educational system should be. If teachers have knowledge of the roles and } \\
\text { responsibilities of the educational audiologist, they will be more } \\
\text { frequently inclined to utilise this support and, as a result, the child with } \\
\text { hearing loss will benefit from these support services (Johnson, Benson \& } \\
\text { Seaton, 1997). }\end{array}$ \\
\hline & Question 27 & $\begin{array}{l}\text { Information on the necessity } \\
\text { and advantages of receiving } \\
\text { support from the } \\
\text { educational audiologist } \\
\text { when including a child with } \\
\text { hearing loss }\end{array}$ & $\begin{array}{l}\text { To determine whether (1) participants had knowledge of the advantages of } \\
\text { receiving support from the educational audiologist in the inclusive } \\
\text { educational system, (2) participants' opinions on what they thought the } \\
\text { advantages of receiving support from the educational audiologist in the } \\
\text { inclusive educational system should be. If teachers have knowledge of } \\
\text { these advantages they will be more frequently inclined to utilise this } \\
\text { support with resulting benefits for the child with a hearing loss. } \\
\text { (Johnson, Benson \& Seaton, 1997). }\end{array}$ \\
\hline
\end{tabular}




\begin{tabular}{|c|c|c|c|}
\hline \multicolumn{4}{|c|}{$\begin{array}{l}\text { APPENDIX C } \\
\text { continued }\end{array}$} \\
\hline SECTION & QUESTIONS & TOPIC & JUSTIFICATION \\
\hline & Question 28 & $\begin{array}{l}\text { Information on the } \\
\text { challenges faced by teachers } \\
\text { when including the child } \\
\text { with hearing loss }\end{array}$ & $\begin{array}{l}\text { To determine participants' opinions on what they thought the challenges } \\
\text { might be when educating the child with hearing loss in an inclusive } \\
\text { educational system. The transition toward an inclusive educational system } \\
\text { will undoubtedly present challenges to teachers that need to be identified. }\end{array}$ \\
\hline & Question 29 & $\begin{array}{l}\text { Information on the possible } \\
\text { suggestions to address these } \\
\text { anticipated challenges }\end{array}$ & $\begin{array}{l}\text { To explore participants' suggestions on how to overcome the challenges } \\
\text { they identified in question } 28 \text {, as suggestions may be incorporated in a } \\
\text { proposal for an educational audiology service delivery model. }\end{array}$ \\
\hline & Question 30 & $\begin{array}{l}\text { Information on the } \\
\text { advantages or disadvantages } \\
\text { of including the child with } \\
\text { hearing loss }\end{array}$ & $\begin{array}{l}\text { To determine participants' opinions on what could be the advantages or } \\
\text { disadvantages of the inclusive educational system for the child with a } \\
\text { hearing loss. Some potential disadvantages could be addressed by an } \\
\text { educational audiologist. The advantages identified may highlight the } \\
\text { possible success teachers may have when educating the child with hearing } \\
\text { loss. }\end{array}$ \\
\hline
\end{tabular}




\section{INFORMATION FOR CONTRIBUTORS}

\section{NATURE OF PUBLICATION}

The South African Journal of Communication Disorders publishes reports and papers concerned with research, and critically evaluative theoretical and philosophical conceptual issues dealing with aspects of human communication and its disorders, service provision, training and policy.

The South African Journal of Communication Disorders will not accept material which has been published elsewhere or that is currently under review by other publications.

\section{MANUSCRIPT STYLE AND REQUIREMENTS}

\section{Preparation of manuscript}

Articles must he accompanied by a covering letter providing the author's address, telephone and fax numbers and e-mail address. Articles must be typed on A4 pages in double spacing and in a font size of 12.

Three print outs of the article must be submitted.

ONE exact copy of the article on disk must be submitted. Filenames must include the first author's initials and a clearly identifiable key word and must he type-written on the last line of the last page of the Reference list (for retrieval purposes only).

Articles must not exceed 30 pages.

\section{Title page}

The title page of ONE must contain:

Title of the article.

Full names of the authors.

Institutional affiliation.

Abstract of the article in the language of the article.

The title page of the remaining TWO copies must NOT contain the authors' names or institutional affiliations.

\section{Abstracts and key words}

Each article must contain an abstract of no more than 200 words.

All abstracts must be in ENGLISH, irrespective of the language in which the article was written.

Each article must provide 5-7 KEYIWORDS for indexing purposes.

\section{Body of Article}

All contributions are required to follow strictly, the style specified in the Publication Manual of the American Psychological Association (APA

Pub. Man., 2001).

- Headings are NOT NUMBERED. The order of importance is indicated as follows:

- Main heading in capitals and bold print.

- Sub-headings in capitals, bold and italic print

- Sub-subheadings in upper and lower case bold and italic print.

- Sub-sub-sub-heading in upper and lower case bold print.

- Major headings, where applicable, must be in the order of INTRODUCTION, METHOD, RESULTS, DISCUSSION, CONCLUSION, ACKNOWLEDGEMENTS and REFERENCES.

- All paragraphs should be indented.

Tables, figures and illustrations

Al tables, figures and illustrations must be numbered and provided with titles.

The title of tables, which appear above, and of figures, which appear below, must he concise but explanatory.

Allow for $50-75 \%$ reduction in printing of tables, figures and illustrations.

Each table, figure or illustration must appear on a SEPARATE page and be print ready. Preferable NOT printed on colour printers.

\section{REFERENCES}

References must be cited in the text by surname of the author and the date, e.g., Van Riper (1971).

Where there are more than two authors, after the first occurrence, et al. may be used from the start.

The names of all authors must appear in the Reference List, which must be listed in strict alphabetical order in triple spacing at the end of the article.

All references must be included in the List, including secondary sources, (APA Pub. Man. 2001)

Only acceptable abbreviations of journals may be used, (see DSI-1 ABSTRACTS, October; or The World List of Scientific Periodicals).

The number of references should not exceed much more than 30 unless specifically warranted.

\section{Examples}

Locke, J.L. (1983). Clinical Psychology: The explanation and treatment of speech sound disorders. J. Speech Hear. Disord., 48 339-341

Penrod, J.P. (1985). Speech discrimination testing. In J. Katz (Ed.), Handbook of clinical audiology (3rd ed.). Baltimore: Williams \& Wilkins.

Davis, G. \& Wilcox, M.J. (1985). Adult aphasia rehabilitation: Applied pragmatics, San Diego, CA: College-Hill.

\section{EDITING}

Articles must be revised for grammar and style prior to submission.

The manuscript style of the article must be strictly according to the guidelines provided.

Only articles complying with the above requirements will be accepted for review.

\section{REVIEWING SYSTEM}

The peer review of refereeing system is employed as a method of quality control of this publication.

Peer reviewers are selected by the editor based on their expertise in the field and each article is sent to two independent reviewers to assess the quality of the manuscript's scientific and technical content. The blind peer review system is employed during which the names of the author/authors are not disclosed to the reviewers.

The editor retains the final responsibility for decisions regarding revision, acceptance or rejection of the manuscript.

\section{DEADLINE FOR CONTRIBUTIONS}

30th January each year

\section{QUERIES, CORRESPONDENCE \& MANUSCRIPTS}

Address to: The Editor,

South African Journal of Communication Disorders

South African Speech-Language-Hearing Association

P.O. Box 5710

THE REEDS

0158

South Africa

\section{Copyright}

The copyright of all articles printed in The South African Journal of Communication Disorders is reserved by The South African SpeechLanguage-Hearing Association (SASLHA).

Do not include more than 10 tables, figures or illustrations. 